\title{
The First Fifty Years of the École des Hautes Études Commerciales de Montréal: from "School of Higher Studies" to University Business School
}

\section{David McKeagan}

\begin{abstract}
The École des Hautes Études Commerciales de Montréal (HEC) held its first classes in September, 1910. The academic program which was transplanted from Belgium was chosen by Quebec political leaders. Its content was aimed at training men for the diplomatic corps and international commerce. Montreal businessmen saw no need to hire men with such training. It took nearly fifty years of conflict between the Montreal business community and conservative forces within Quebec society before this legacy was overcome. Eventually, candidates were better schooled to give them a chance to become leaders in the Quebec business community. HEC's early history is a mirror of a wider struggle to gain equal recognition for practical training in medicine, engineering, and business which faced strong resistance from an elite trained in the humanistic tradition.
\end{abstract}

\section{RÉSUMÉ}

L'École des hautes études commerciales de Montréal (HEC) a offert ses premier cours en septembre 1910. Son programme d'études, emprunté à la Belgique, a été choisi par des chefs politiques québécois. Il visait à former des diplomates et des spécialistes du commerce extérieur. Pour leur part, les hommes d'affaires montréalais ne voyaient pas l'utilité d'embaucher des diplômés avec ce genre de formation. Il a fallu presque cinquante ans de conflit entre la communauté des affaires montréalaise et les forces conservatrices dans la société québécoise pour triompher de cet héritage. À la longue, la formation des étudiants de l'École s'améliora et ils purent avoir davantage d'opportunités pour devenir des membres importants du milieu d'affaires québécois. L'histoire des débuts de la HEC reflète une lutte plus grande encore pour une reconnaissance équivalente de la formation professionnelle que ce soit en médecine, en génie ou dans le commerce de la part d'une élite formée à la tradition humaniste.

\section{Introduction}

Most modern universities evolved according to the German model which developed during the nineteenth century. As the importance of religion and the 
education of religious leaders decreased, greater emphasis was placed on academic freedom, research, seminars, and publication. The sciences garnered a respected place alongside the humanities. Although the main objective of universities was to train students' minds, actual skills training increasingly became a part of curricula so that even architecture and engineering were incorporated into program offerings. The last set of disciplines to assault the ivory towers were the business subjects; however, universities did not accept business education without a struggle. When a business program was first proposed at Princeton University, its president Woodrow Wilson remarked: "Why, you wouldn't have the colleges teach business, would you?" Charles Cochrane, a professor of ancient history at the University of Toronto, considered the introduction of commerce courses to be "an unparalleled confusion in educational values," because the curricula of commerce programs emphasized the "cultivation of power" at the expense of the "power of culture." Traditional academics undoubtedly felt that granting college degrees for business training would give business and its practitioners a level of respectability they did not deserve.

It can be argued that the humanities provide an appropriate basic training leading to any career, but more directly to journalism, politics, and law, for example. In the same way mathematics, physics, chemistry, and biology are important elements in training engineers and medical practitioners. Indeed university training became almost essential for entry into these applied professions. Business does not fit this pattern well because until recently, on-the-job training was considered to be all that was necessary. Modern education for business developed not from the universities but from industry, which helps explain why business came later to academia. Alfred Chandler has described what he calls the managerial revolution that took place in the United States. This led to the development of management as a profession and occurred in the large modern multiunit business enterprise which gradually displaced small traditional business during the nineteenth century. ${ }^{3}$ These businesses found that employing trained administrators achieved greater productivity, lower costs, and higher profits. The individuals who filled these roles increasingly had technical training and became members of an emerging profession which had its own associations and journals. ${ }^{4}$

Even earlier than this development, training in clerical subjects became widespread in the nineteenth century in Europe and North America. Quebec followed this trend. According to Claude Galarneau, commercial programs had been established at the classical colleges in Montreal and Quebec by 1830 since it was deemed urgent to give young people some ideas about accounting, bookkeeping, English and other subjects of practical use in business and even agriculture. ${ }^{5}$ In his history of the Nicolet Seminary, Claude Lessard also notes that due to American influence a "classe commerciale" became an option in most of the classical colleges early in the nineteenth century. However, critics decried the practice since it produced superficial men. ${ }^{6}$ Such programs were essentially at the primary school level. Thus, the institutions providing this training made no effort to develop business management as a science. 
A twentieth century development was the introduction by many universities in the United States of more advanced programs which deemphasized the routine of clerical programs but did not go beyond teaching specific skills such as accounting and languages. The Harvard Business School's case method was the first to incorporate developments from the managerial revolution and to develop substantive research programs. Leaders in Quebec education were aware of these developments but a cultural attachment to French speaking countries in Europe led them to follow models from this source.

Although large numbers of students passed through the commercial classes of the classical colleges one should not assume that they were incubators for future entrepreneurs. In his memoirs, Claude Carbo notes that they took English lessons but that they were associated with "le détestable Protestantisme religieux." $\mathrm{He}$ notes from George-Émile Lapalme's autobiography that regular students looked down on those in the commercial program and that they were also indoctrinated to pursue "notre mission en terre d'Amérique." 8 Future historian Marcel Trudel was an example of one who showed independence of spirit: he was expelled!' The classical colleges also systematically eliminated lay teachers who might have brought useful experience to their teaching and act as role models for future scientists, engineers, and businessmen. Young seminarians who gave these courses could hardly be expected to do this.

In opposition to the approach of the Classical Colleges there was a movement in Quebec for more practical education. One high point of this movement was the opening by the Montreal Catholic School Commission of the Ecole Doran, a primary school, in 1854. This school employed lay teachers and taught commercial subjects; it would be renamed the Académie Commerciale Catholique de Montréal in 1860 under its new director Urgel-Eugène Archamault. ${ }^{10}$ In 1873, Archambault launched a more advanced applied science program which would become the École Polytechnique de Montréal; ${ }^{11}$ classes were held in an annex to the Academy. In 1876 the Quebec legislature granted Poly the right to grant engineering degrees to graduates of its three year program. ${ }^{12}$ Due to lack of funds Archambault could not afford to hire graduate engineers to teach the courses. Initially, the professors were French speaking Europeans with some scientific training. They imparted the French notion that engineering programs should be general in nature as opposed to the specialization practiced throughout the rest of North America. Although the curriculum was intended to include some specialization, in practice it was a civil engineering program. The classical colleges did not promote it as an outlet for their graduates and prominent French speaking businessmen did not send their sons there. Industry was wary of the content of Poly's program and most graduates had to find jobs in teaching or in government. This scenario was replicated almost to the letter with HEC's experience thirty-years later.

A severe handicap for Poly was the problem that most entering students had only a primary education or additional normal school exposure. Secondary education in French schools hardly existed outside the classical colleges. These were private institutions run by the clergy that offered an eight-year program to primary school graduates after six or seven years of elementary schooling. The curriculum prepared 
students for the clergy and the liberal professions. According to Linteau et al, "education for scientific careers was shockingly neglected... the system was clearly inadequate to meet the needs of an industrialized country that required skilled workers and specialists in science and management."13

From the middle of the nineteenth century the teaching Brothers had promoted primary education which aimed to prepare boys for employment in commerce and industry. Early in the twentieth century, many reformers came to advocate a rationalization that would align primary school programs such as those taught by the Brothers with those of the professional schools such as Poly and HEC. Thus began the movement to establish the cours primaire supérieur. This would mean adding three years to the eight-year Academy program. The law was adopted in 1911, but the program was not operational until the 1920s. There was a movement to give something equivalent to the English high school. Several orders of teaching Brothers were interested in this approach and the first program was launched by the Clercs de St-Viateur in 1920. ${ }^{14}$ An important handicap faced by the teaching Brothers was that it was assumed they came from working class backgrounds and that their instruction was aimed primarily at children from a similar social status. The Catholic clergy fought hard to secure the perception that these programs were inferior to what was taught in the classical colleges. Further resistance came from the nationalist movement which resented the importance placed on English instruction.

The founding of the École des Hautes Études Commerciales de Montréal (HEC) was a major turning point in Quebec's educational history. It was legally established through legislation piloted by Premier Lomer Gouin. In various official pronouncements about the future HEC he referred to expectations for its graduates. He stated that "Dans notre province, les études qui préparent aux professions libérales trouvent bien un couronnement dans notre enseignement universitaire mais il n'est pas ainsi pour l'enseignement industriel," implying that the HEC would also be a university. ${ }^{15} \mathrm{He}$ stated further that his objective was to "donner à notre province des négociants éclairés, des chefs de maisons de commerce et de banques...," suggesting that graduates would become senior decision makers. Further confirmation of this objective comes from Esdras Minville, a 1922 graduate and HEC principal from 1938 to 1962 . He said that "Former une élite commerciale, industrielle et financière : tel était l'objet assigné par les fondateurs à l'École des Hautes Études commerciales." 16

Given that the objective of founding HEC was to give French speakers leadership roles in the Quebec economy, how successful was it? An attempt to measure this was made by selecting a baseline from a Quebec "Who's Who" of 1920. Among the 381 citations in this edition were 140 people (37 percent) who were classified as merchants, businessmen, industrialists, financiers, contractors, brokers or bankers. Of these about one third had some classical college training which was typically obtained in a commercial program and often combined with business college exposure. ${ }^{17} 1960$ was chosen as a year to compare with 1920 because this was before any impact could be felt from the educational reforms initiated by Jean Lesage and subsequent Quebec governments. (It was also 50 years after the first HEC graduating class in 1910). Among the 600 people cited in the 1960 edition were 242 (40 percent) who were 
classified in the different business categories cited above. ${ }^{18}$ Among these different type of "businessmen" 16 (7 percent) had attended HEC; three of these had a licence en sciences commerciales and one a bachelor's degree in commercial sciences. The rest would have taken night or correspondence courses at HEC or only completed part of the degree requirements. Comparison of these two samples shows that the pattern of education leading to a business career hardly changed over 50 years. The surprising conclusion is that the HEC had little impact on the training of business leaders. The remainder of this article will attempt to explain this by covering four subjects which touch on HEC's history: the origins of HEC and the history of its first fifty years, in the broader context of practical education in Quebec; the evolution of post-secondary business education in Europe and North America leading to the incorporation of management science; the place of HEC in this process; and the status of secondary education in Quebec which impacted the development of post-secondary education in engineering and medicine as well as business.

While the primary research for this essay relied on the HEC experience, an effort has been made to complement the work of Barry Boothman on the history of business education in Canada. ${ }^{19}$ The other essays in Austin's book were written by career staff of Canadian university business faculties and are primarily anecdotal. Boothman traces the evolution of business training in Canada but does not fully explain where and how the transfer of business science from industry to academia took place.

\section{Literature Dealing with HEC History}

Two published accounts were sponsored by the HEC itself. As with the individual histories of Canadian business schools in Austin's book, ${ }^{20}$ these were mostly anecdotal. ${ }^{21}$ However, in keeping with HEC's deserved reputation for harboring strong French Canadian nationalist sentiments, they blamed their compatriots' economic inferiority on the domination of the Quebec economy by English speakers. They accorded to the Chambre de Commerce du District de Montréal (the Chambre or CCDM) an important role in the founding of HEC, which we hope to show was not deserved.

These authors downplayed conflicts between a French Canadian elite educated in the classical colleges and a business community most of whose members had many fewer years of schooling which had been more practical in nature. This social divide would be detrimental to the development of the HEC. It was not the businessmen of the Chambre but the Liberal Premier Lomer Gouin who found a compromise with the Church that allowed the Government to initiate improvements in technical and business education. ${ }^{22}$

In an unpublished history of the HEC's early years, François-Albert Angers offered a credible explanation for how this social divide was maintained. ${ }^{23}$ Priests teaching in the classical colleges were for the most part convinced that a career in commerce was inferior to one in the liberal professions. They communicated this attitude to their students who were thus disinclined to go into business or engage in business studies. They also wanted to ensure that nothing was done to raise the social status of businessmen to that of lawyers, doctors, and priests. 


\section{Divergent Views Mark the Launching of the HEC}

Gouin's fellow Liberal and member of the federal parliament, Honoré Gervais, had his own agenda for commercial education. Gervais was convinced that specialized schools should be created across Canada, whose mission would be to train consular officials. He developed this theme in a 1901 article in La Patrie. ${ }^{24}$ Speaking in the federal parliament as a recently elected MP for St-Jacques in 1904, Gervais said it was time that Canada was represented abroad by her own nationals and that they should be trained in écoles supérieures de commerce, which should be created. ${ }^{25}$

Interest on the part of the Chambre in Canadian commercial agents predates Gervais' earlier intervention. During a discussion of improvements to the port of Montreal in May 1900, Alphonse Desjardins made the point that Canada should be represented in foreign countries by her own consular agents. This need was especially pressing in Paris where Canada had diplomatic representation only. ${ }^{26}$ In December of the same year, Joseph Fortier spoke about naming commercial agents to represent Canadian businessmen and manufacturers abroad. ${ }^{27}$ At the next meeting, a resolution was passed supporting the establishment of commercial agents in foreign countries. This was sent to the Prime Minister in Ottawa. ${ }^{28}$ Desjardins reiterated his position on foreign representation during a meeting in early $1901 .^{29}$ A special committee was formed to study the importance of having properly trained Canadians to represent their country abroad. As chairman of this committee, Desjardins reported at the 1 November meeting that the Canadian Manufacturing Association had been lobbying the federal government along the same lines.

Interest in this proposal received no further notice on the part of the Chambre after Gervais' pronouncements. Members had divergent ideas on what should be done to improve commercial education. A motion for formation of a merchant marine school in Montreal was made in 1902, along with the suggestion that practical training could be given in the summer on Coast Guard vessels. ${ }^{30}$ Public courses on commercial geography were proposed in 1902, but nobody could be found to teach them. ${ }^{31}$ Since navigation courses were being given at the Monument National, former Chambre president Damase Parizeau recommended in 1903, that a navire-école be established for the practical courses. ${ }^{32}$ In 1906, the establishment of an école de coupe et de couture to train young women was discussed. ${ }^{33}$ The Chambre members were certainly in favor of the provincial government taking steps to improve commercial education. If there was a common thread, it was an emphasis on external maritime commerce; but there was no consensus on how to proceed. This interest in shipping could have been part of the reason for calling the first diplomas granted by the Montreal HEC a licence en sciences commerciales et maritimes; but it was left to the government to make things happen.

Change was initiated on 23 March 1905, when Lomer Gouin took over the leadership of the Quebec Liberal party and became the Premier of the Province. At a by-election meeting on 5 April in Montreal presided over by Honoré Gervais, Gouin gave a speech outlining the program he intended to implement. ${ }^{34}$ Prominent among his priorities were a number of initiatives directed at improving education, 
including the creation of technical schools, and an école des hautes études commerciales. ${ }^{35}$ This story received front-page coverage in pro-Liberal newspaper Le Canada the following day. In subsequent issues, there were individual editorials discussing the merits of each of the proposed schools.

Neither Le Moniteur du Commerce nor Le Prix Courant, the two Montreal newspapers whose market was local businessmen, made any comment on Gouin's proposals. It was not until June 1906, more than a year after Gouin's announcement of the HEC, before the first editorial comment appeared in Le Prix Courant on the subject of Gouin's specific proposals for improved commercial and technical education. The published HEC histories identified the CCDM as the sponsor of the HEC project. In support of this thesis, Fernande Roy described the Chambre at the turn of the twentieth century as an organization of French Canadian businessmen of growing importance. Roy found the first decade of the twentieth century to be a particularly dynamic period of its history. She said that the best example of its success was: "l'École des HEC pour laquelle on crée une commission spéciale où siège Lomer Gouin." ${ }^{6}$ This claim is not supported by what the members of the Chambre discussed and what initiatives they took.

The Chambre held its first meeting on 2 February 1887. The members formed twenty permanent committees to study issues of concern. Education was not one of them. As outlined above, meeting minutes show sporadic but unfocused interest in improving practical education over the years but the first serious initiative came from George Gonthier. A letter he had sent to the Chambre was published in its December 1900 Bulletin. He had asked the Chambre to consider the program at the New York University School of Commerce, Accounting, and Finance. ${ }^{37}$ If Gonthier's advice had been followed the new school would have specialized in producing accountants. However, at the beginning of the twentieth century, the accountancy profession did not have a reputation for professionalism comparable to that of lawyers and doctors, or even engineers. This approach was not what Gervais and Gouin had in mind.

On 23 May 1906 George Gonthier informed the Chambre board that École Polytechnique had asked for government funds to build a laboratory and establish a chair of hautes études commerciales. ${ }^{38}$ Le Prix Courant announced about the same time that an HEC would be founded at Laval University (Montreal). ${ }^{39}$ Over the next few months, board meeting minutes recorded many discussions about different scenarios for the establishment of the proposed institution.

However, the Chambre meeting minutes do not reveal the full extent of the debates within this organization. On 19 September, Le Canada published a letter to the editor, written two days earlier by someone using the pseudonym "Commerce." 40 He asserted that he had been a member of the Chambre almost from its inception and complained that despite having nearly 800 members, only a small fraction of that number were actually active. They always seemed to discuss the same issues and they often ignored questions that were important to business. The correspondent cited a resolution just passed by the Chambre, asking the government to establish a chair of political economy at Laval University. He said that they could do a lot 
more than concern themselves with abstract theories that had no direct application to business. He felt that what was really needed was a school where commercial college graduates could extend their knowledge. This could not be done without money to construct a building and hire professors. He exhorted the Chambre to do this through a financing campaign among its members and then ask the government to help with the funding of running the school. He reminded them that this was how it was done in Europe. The sentiment expressed in this letter to the effect that the Chambre was reluctant to take real responsibility for the project was echoed in Lomer Gouin's speech of 8 March, 1907: “C'est l'Allemagne qui, par ces initiatives privées, par l'action de ces Chambres de commerce, de ces grandes corporations et de ces philanthropes, s'est placée à la tête de ce mouvement progressif et elle le dirige encore. Contrairement à ce que nous sommes forcés de faire ici, son gouvernement n'est guère intervenu dans la création et le maintien de l'enseignement technique." ${ }^{41}$

In September 1906, the Chambre board passed a resolution forming a permanent committee, whose mandate was to pursue all means necessary for the establishment of an HEC. ${ }^{42}$ Isaïe Préfontaine was elected chairman. This committee met with Premier Gouin on 20 December 1906. Only after this meeting was the idea of a completely separate facility not associated with existing institutions openly acknowledged. The Chambre then moved that the Government build a facility and that the school be administered as a corporation by a board of directors chosen from members of the Chambre, and approved by the government. ${ }^{43}$ They offered an annual subsidy of $\$ 5,000$ provided that the building would eventually belong to the Chambre. The legislation establishing the HEC stipulated that the Chambre “...shall pay a sum of $\$ 5,000$ a year, for forty years..." ${ }^{44}$ This was amended a year later by replacing the word "shall" with "may." 45 There is no record in Chambre minutes indicating that any money was paid towards the HEC. Fernande Roy noted however that: "la situation financière de la Chambre est suffisamment bonne en 1909 pour lui permettre l'achat de son propre immeuble." ${ }^{6}$ Unlike their counterparts of the European Chambres, Montreal businessmen confined their support to the moral side.

Legislation creating the Montreal HEC was signed into law on 14 March 1907. It stipulated that the Board of Directors be composed of the school principal and five members of the Chambre. In placing the direction of the HEC entirely in the hands of Chambre members, Gouin was recognizing the importance of their support for the future staff and graduates. From a list of names submitted to the Quebec Government for approval, Isaïe Préfontaine, ${ }^{47}$ Honoré Gervais, Joseph Contant, ${ }^{48}$ C.F. Smith, ${ }^{49}$ and Honoré Mercier ${ }^{50}$ were selected. Préfontaine was elected president and Mercier secretary-treasurer of the Board. George Gonthier's name was on the list of thirteen candidates submitted by the Chambre, but he was not chosen. This is surprising since he had been the most persistent crusader for improved commercial education. Since Gervais and not Gonthier was made a director, the conclusion must be drawn that Gouin did not want a director involved who did not favor the European style consular school. ${ }^{51}$ According to Angers, Gervais was the driving force and the Chambre merely a front. ${ }^{52}$ 


\section{Business Education in Europe and the United States}

It was Quebec political leaders who decided that they would create an HEC. They also decided that it would be modeled on European forms of commercial education. European interest in practical education grew rapidly during the nineteenth century, as a response to the expansion of business and industry, and the disappearance of the apprenticeship system. Parallel with this trend was a movement within the liberal professions to form associations and establish standards for admission. Some members of the business community hoped to achieve something similar while overcoming the traditional stigma of inferiority attached to business as a career.

The first concrete initiative to advance the status of businessmen took place in Belgium where the Institut Supérieur de Commerce d'Anvers (Antwerp) began a twoyear program of commercial studies in 1853. The sponsors intended that the school be a university of commerce but the existing universities and officialdom objected to putting commercial studies on the same footing as the humanities. The status of the Institut was inferior to existing normal schools, academies, and other intermediate schools of Belgium. ${ }^{53}$ On completing the two-year program, a student was granted a licence en sciences commerciales. Edmund James found in 1889 that almost half the students at the Institut at Antwerp were foreigners and that the Belgian business community had little interest in employing graduates. ${ }^{54}$

Robert Locke noted that commercial education in France developed outside the universities in what were referred to by their promoters as Grandes Écoles, but that because they were not state supported like the Grandes Ecoles of engineering, they could not be considered in the same category. ${ }^{55}$ The Paris HEC was the most important of these institutions. It had mostly part-time faculty; there was no graduate study and no research program. ${ }^{56}$ Hence, no effort was being made to develop the science of management. The Paris HEC was not a university in the modern sense. It aimed to place its graduates in the upper echelons of public administration but was unsuccessful. In 1912, 89 per cent of the Paris HEC students succeeded their fathers in a family business. ${ }^{57}$ The experience in Germany was similar. There was a surge of commercial education start-ups before and after World War I, but the aim was "to provide the sons of businessmen with academic degrees in order to raise... the business profession to the social level of other university educated professions." 58 In some cases educators aimed at advanced education in commerce but there was no clear idea how this would be different from secondary school programs. According to Frederick Farrington, the establishment of post-secondary commercial programs was a result not a contributing cause of Germany's commercial progress. ${ }^{59}$ The cost of this education was high and remained the preserve of the offspring of a growing commercial elite.

Americans had the same motivation as Europeans to promote business education but the former managed to take it to a higher level. Advanced business education in the United States would get its principal impetus when Harvard put its prestige behind the creation of its business school in 1908. The first dean was Edwin Gay, who had taught economic history at Harvard. ${ }^{60}$ The Harvard degree would be a masters 
program aimed at liberal arts graduates. Gay had no illusions about the state of business science. He said in 1908, "from the mass of accumulating business experience, a science must be quarried." 61

Unlike their European and HEC counterparts, the leaders of American business schools were conscious of the management revolution and worked to incorporate emerging knowledge into their curricula. This was reflected in the early development of a significant level of specialization. "Early American business schools adopted the technical training ideal and developed narrowly defined fields such as accounting, finance, insurance, management, marketing, real estate, and transportation." ${ }^{62}$ This matched the way corporate organization was evolving into functional specialties.

The "management movement" is a term which is often used to describe the application of scientific methods to business. This is a synonym for Chandler's "management revolution" applied to a later period; as with Chandler, university trained engineers led the way "with the application of science to manufacturing." ${ }^{3}$ They were guided by mechanical engineer Frederick Taylor's ideas on scientific management. ${ }^{64}$ Taylor became prominent around 1895; he pioneered management by exception where action was taken when operations differed from set standards. The next phase of development was beyond the typical engineer's training. It involved decisions about finance and marketing to which economists specializing in business made significant contributions. This led to the emergence of the corporate controller as a key managerial role. ${ }^{65}$

This movement quickly spread to Canada as well. The agricultural implement manufacturer Massey-Harris was an early adaptor. Other large Canadian firms emerged in the first decade of the twentieth century as a result of the merger movement. The scale of their operations was conducive to the hiring of professional managers. ${ }^{66}$

While specialization was the norm in most American business schools, in the 1920s Harvard implemented the "case study" method which became a new paradigm for advanced business education. Future executives were trained to be general managers by examining all aspects of individual firms' operations. ${ }^{67}$ In this way advances in management practice could be synthesized and diffused through research and publication. In Canada, only the University of Western Ontario attempted to follow this approach before the $1960 \mathrm{~s} .{ }^{68}$ For the most part, Canadian and American universities offered "training in commerce" instead of an introduction to management science, as demonstrated by reports of the Ford and Carnegie foundations in $1959 .{ }^{69}$

Whatever the origins of the management movement, it was almost exclusively an American invention. It was not until the mid-1960s that Europeans came to realize that they were trailing in this domain. In his seminal work The American Challenge, Servan-Schreiber stated that the secret of American dynamism came from the "art of organization." The gap between Europe and the United States was "less technological than managerial."70 Edward Denison wrote earlier that the growing technological gap between America and Europe was "due primarily to the paucity of higher education ...but it is also due to an apparent inability... to grasp and apply modern methods of management." ${ }^{1}$ 


\section{Launching the HEC Project}

Once the decision to import a European program had been taken, hiring a director was the next step. According to Linteau, Gouin took responsibility for this. ${ }^{72}$ From Paris, Canada's representative Paul Wiallard sent an evaluation of three candidates. He recommended that the post be offered to A.-J. de Bray. De Bray was a Professor of Commercial Sciences, Athénée Royal de Namur, he was widely published, and came with strong recommendations from high Belgian officials. In his advice to Premier Gouin however, Wiallard warned of potential problems for the new school. He said that with the exception of the Paris HEC most institutions of commercial education were in trouble. Students were typically ill prepared for advanced studies and so they dropped out or standards were lowered. He suggested a gradual introduction of a program that was appropriate for the level of students graduating from existing courses. Wiallard sent his report to Gouin with a covering letter dated 20 July $1907 .{ }^{.3}$ Willard highlighted a problem that was nearly identical with that faced by Ecole Polytechnique (Montreal) for over thirty years. It seems that Gouin rejected the option of a more gradual introduction of advanced business studies which would have paralled the engineering school's history.

The selection of de Bray was confirmed by the end of September. ${ }^{74}$ De Bray was thirty-three years old in 1907, when he was recommended for the post as principal of HEC. His academic qualifications included: licencié en sciences commerciales (Antwerp), licencié du degré supérieur en sciences commerciales et consulaires (Leuven), et docteur ès sciences politiques et diplomatiques. Among de Bray's credits was the title of Honorary Professor of Commercial Sciences at the Athénée Royale de Namur. The system of athénées, or academic grammar schools, was created in 1842 and taught pupils from the age of twelve to eighteen. ${ }^{75}$ Honorary Professor was the title given to respected staff after they leave. Since de Bray was hired in 1907, he had three years secondary level teaching experience before coming to Montreal. It is unlikely that he had administrative responsibilities prior to taking on the Montreal HEC assignment.

De Bray left Belgium to become the director of the Montreal HEC in 1908, and immediately ran into major administrative challenges. The first was school construction. De Bray spent a significant part of his first two years dealing with a building whose facilities he hoped would compare favorably with those he knew well in Europe. Cost overruns would plague HEC for decades as the interest on the loan covering building costs would be a major budget item. Completion was originally scheduled for the 1909-1910 school year; the building was still incomplete when classes began in October $1910 .{ }^{76}$ Board of Directors meeting minutes show that finalizing construction and rectifying problems related to the building would continue to be a preoccupation for several years after the opening.

The next major problem for de Bray was recruitment of teaching staff. Among Quebecers, only Edouard Montpetit was qualified to teach business subjects. ${ }^{77}$ De Bray had no choice but to recruit men for non-business subjects who were already teaching elsewhere and businessmen from Montreal with no teaching experience. They were part-timers, a problem that was not unique to HEC. According 
to Paul-André Linteau, "l'Université Laval à Montréal compte essentiellement sur des prêtres et sur des professeurs lä̈ques qui n'exercent cette activité qu'à temps partiel."78 Because of these problems, de Bray does not appear to have moved very swiftly. The first record of a request to approve appointments was in June $1910 .^{79}$ Since de Bray said he could not find suitable professors in Quebec for some courses, or lab equipment for practical work, he was given approval to find both in Europe. He left to do this in August, only weeks before the school was scheduled to open. As a result of de Bray's trip to Europe, Henry Laureys was hired to teach economic geography and G. Lechien to teach physics and chemistry. Both were graduates of the University of Louvain in Belgium. They were unable to get to Montreal before the start of courses and de Bray had to fill in until they did. ${ }^{80}$

In November 1909, the HEC board of directors approved the three-year program of studies outlined by de Bray. ${ }^{81}$ The school's principal detailed the important elements of the courses in an article written for the Revue Économique Canadienne. ${ }^{82}$ The four course groupings were: commercial practices (accounting, geography, organization, shipping, and advertising, taught in a simulated commercial office); language and literature (English, French, German, Italian, Spanish, business history, and moral philosophy); science and technology (algebra, chemistry, industrial processes, commercial products, port regulations, ship construction, communications, and transport); and economics and law (political economy, civil law, commercial law, maritime law, customs regulations, consular conventions, and statistics). A graduate would become a Licencié en sciences commerciales et maritimes. While de Bray had been encouraged to take into account what was being taught at American universities, the program copied Anvers closely. This was essentially "commercial training" as opposed to "business education" to use Jean Marceau's terms. ${ }^{83}$

Accounting, which Georges Gonthier considered so important, would be a small part of the HEC's commercial office activities. Bookkeeping was taught and little more. According to Harvey: "au début, il n'y aura donc pas de cours de comptabilité proprement dit." ${ }^{4}$ From 1911 to 1916, a unilingual English-speaking professor, Robert Sugars, taught accounting. Potential employers complained that the students absorbed very little accounting because they were taught a subject that was foreign to them in a language that was also foreign to them. And yet the accounting profession had a growing representation in the Chambre. In 1901, eight members listed their occupation as accountant. ${ }^{85}$ In 1909 , this number had risen to thirty-six. ${ }^{86}$ There is no indication that any of these members were asked to teach accounting, although George Gonthier was invited to replace Sugars in 1916. He turned down the offer.

Principal de Bray soon had to face the problem that the first students who applied were under-qualified. In one of the first articles written in the HEC journal, de Bray noted that an extra preparatory year was being considered in some secondary schools. ${ }^{87}$ Errol Bouchette pointed out that both HEC and the École Polytechnique would continue to have problems with recruitment until secondary education was improved. ${ }^{88} \mathrm{HEC}$ was not in any position to change secondary programs to suit its needs and it would be forced to initiate preparatory years. ${ }^{89}$

Another problem related to the Quebec environment was the lack of opportunity 
for graduates of HEC. Before there were any graduates, de Bray made a serious effort to sensitize Quebec society to their potential. On October 26, 1910, he gave a long speech during the Chambre meeting on "Le rôle du licencié en sciences commerciales dans le développement économique d'un pays." ${ }^{\prime 0} \mathrm{He}$ said that university level commercial education prepared students to be leaders of commercial, industrial, financial, and maritime enterprises as well as to become high-level government officials. He emphasized that such graduates were prepared "plus particulièrement pour le service consulaire dont les agents ont pour mission de rechercher des débouchés pour les industries nationales." He made the point several times that university level commercial education was meant to do much more than the technical schools which prepared graduates to be skilled tradesmen or foremen.

When building costs started to get out of control, press criticism of Gouin's HEC project escalated. The original legislation provided for $\$ 300,000$ in loan guarantees and a subsidy of $\$ 20,000$ per year. These amounts were amended to $\$ 500,000$ and $\$ 30,000$ per year in April 1908 and to $\$ 600,000$ and \$50,000 per year in June 1910 . A Le Devoir editorial in October referred to the HEC as a white elephant. ${ }^{11}$ This article accused Gouin of wasting taxpayers' money just to get his name on the corner stone of a civic monument. The editorialist was prepared to accept the project if it could provide a valuable education to the students. What he could not accept was the religious neutrality of the school. It should be run under the auspices of the Church, to ensure religious conformity.

With pressure from the press along with all his other problems, it is safe to say that de Bray was overwhelmed by the task facing him. Rumors circulated about professors' frequent absences and lack of discipline in the classes. The minutes of the Chambre board meetings leave the impression that all was well at the HEC. Board members made their annual visit to the school, de Bray put on an impressive show, and everyone went away satisfied. The minutes of the HEC board tell a different story. The school principal had to justify the smallest of expenditures and there was frequent conflict over staff appointments. Lomer Gouin was undoubtedly made aware of these problems and he uttered a public signal of alarm during a speech at the first annual HEC banquet held on 23 February 1914. He complained that the Chambre was uninterested in the institution that had been founded at its request. President Adélard Fortier wrote to Gouin to defend the Chambre. He claimed that the Chambre had not been consulted on the HEC program and that it had not responded to their request for night courses. ${ }^{92}$ If the Chambre had not been consulted on the school's program, then historians' claim that the Chambre founded the school are somewhat tenuous. The Bulletin confirmed that at the June 1912 meeting of the board of directors, Préfontaine had spoken about the Chambre's request for night courses. At the same time, he painted a very rosy picture of the school's operations. There seems to be no reason for Préfontaine to have hidden problems from his colleagues, but he did. There were other HEC directors and a permanent commission of the Chambre responsible for HEC matters, but if they thought there were problems they did not raise them. 1916 was a year of major change at HEC, but the Chambre directors never discussed the subject. ${ }^{93}$ 
Rumors of problems reached Gouin's opponents, and pointed questions were asked in the Legislative Assembly. The entering class of 1910 was reduced by attrition from 32 to 19 for the second year. Of these, only 9 graduated in 1913. Of 30 first year students in 1913, only 6 graduated in 1916. The cost per graduate was deemed to be very high. Graduates had difficulty finding jobs so Préfontaine asked that students get more practical training. De Bray resisted because his mandate was to run an École Supérieure not a secondary school.

Finally, Préfontaine decided to act. In a 14-page letter to Premier Gouin, dated 9 March 1916, Préfontaine detailed the list of grievances against de Bray. Gouin reluctantly agreed with the assessment, and the board asked for de Bray's resignation.

\section{A New Director at HECM}

Before scientific management had a significant impact on post-secondary American business education, HEC continued to struggle with opposing views on what should be taught. Henry Laureys, who became the new principal in 1916, received his postsecondary education at the École des sciences commerciales et consulaires and received his licence in 1906 at the age of 24 from the University of Leuven. From graduation until 1910, he served on the Belgian Government's training ship L'Avenir. ${ }^{94} \mathrm{He}$ was hired by de Bray to teach economic geography. In his history of geography at McGill, Brian Bird noted that Laureys was the first professor of geography to be appointed at a Canadian university. ${ }^{95}$ Laureys would sponsor several graduates for study of geography in France so they could return to teach at HEC. This and a survey of theses topics show that he reinforced geography as the central theme of the HEC curriculum during his tenure. In 1931, Laureys received his doctorate from the University of Montreal for a thesis entitled La conquête des marchés extérieurs.

During the first few years of HEC's existence it is clear that Chambre representatives and Premier Gouin differed significantly on what sort of program HEC should offer. De Bray was replaced by Henry Laureys who could not have obtained this position if he did not share Gouin's perspective. The day program leading to a licence evolved slowly. He did make a concession to the CCDM in the realm of specialization. Training for accountants was migrating to universities in North America; he led the battle to obtain equal recognition for HEC accounting graduates with those from McGill. Pierre Harvey has written about the long struggle waged to promote accounting among French Canadians. ${ }^{96}$ Laureys responded to the perceived needs of Montreal businessmen. Night and correspondence courses became an important activity for the teaching staff, as shown by the figures on the next page. ${ }^{97}$

Thus Laureys created two parallel streams of learning. Specialization would be taught to part-timers to satisfy local demands while the flagship program leading to a licence remained essentially unchanged.

In 1926, under the guise of better controlling costs, the Quebec Government formed the Corporation of Technical and Professional Schools. HEC lost its independent status reporting to a board composed of CCDM members. In reality it was a recognition that the CCDM continued to deny full support to the HEC and that 


\begin{tabular}{|c|c|c|}
\cline { 2 - 3 } \multicolumn{1}{c|}{} & \multicolumn{2}{c|}{ Number of Students Enrolled in year } \\
\cline { 2 - 3 } \multicolumn{1}{c|}{} & $\mathbf{1 9 2 3}$ & $\mathbf{1 9 3 6}$ \\
\hline Regular Program & & \multicolumn{1}{c|}{} \\
\hline Preparatory Classes & 42 & 65 \\
\hline First Year & 39 & 70 \\
\hline Second Year & 26 & 49 \\
\hline Third year & 14 & 32 \\
\hline Total & $\mathbf{1 2 1}$ & $\mathbf{2 1 6}$ \\
\hline Part-time Program & 212 & 813 \\
\hline
\end{tabular}

their program was not more advanced than those of the technical schools. Henceforth Laureys reported to the Provincial Secretary Athanase David.

As one of the few lay administrators in Quebec education, Laureys had to take a stand on an emerging controversy over the place of research in higher education. In 1920 when the University of Montreal gained its independence from Laval University, it set up a science faculty to improve medical training as recommended by the Rockefeller Foundation. Brother Marie-Victorin, who had established an international reputation in botany, was recruited to teach this subject. At the time, biology was being taught by L.-J. Dalbis. Marie-Victorin was an advocate of the approach practiced in German and American universities of combining active research with teaching; Dalbis who was educated in France kept abreast of his subject by reading and was not inclined to do research. In 1923 Marie-Victorin, Dalbis and radiologist Léo Parizeau founded the Association canadienne-française pour l'avancement des sciences (ACFAS). Soon there arose a professional conflict between the two botanists which led Dalbis to resign from the ACFAS. In 1927, Dalbis founded the Institut scientifique franco-canadien (ISFC). This organization obtained grants from the provincial government and the University of Montreal to bring in visiting professors from France to give conferences. This undermined the activities of the ACFAS according to Marie-Victorin. ${ }^{98}$ Laurey's unqualified support for the ISFC and disdain for ACFAS translated into the recruitment of a number of specialists from France to give conferences at HEC every year from 1929 to $1937 .{ }^{99}$

A further incident in the debate about approaches to post-secondary education is sometimes referred to in the literature as the "Rousseau affair." Esdras Minville had published two articles in L'Action nationale of April 1934. In these he defended HEC's model which followed the French Grandes Écoles and castigated his compatriots for their "anglomanie." He inveighed against the training of scientists to work in industries which did not belong to the Quebec people. A rebuttal was published in L'Ordre later in the year by Jacques Rousseau. ${ }^{100}$ Rousseau claimed that it was the scientists who were raising the standards of education in Quebec as opposed to the HEC which provided no more than a primary level education. He further claimed that the school's journal L'Actualité économique was nothing more than a "bulletin d'Amicale." 101 
One trend which accompanied professionalization was the formation of organizations directed at raising standards. In the United States, the American Association of Collegiate Business Schools (AACBS) was formed in 1916. According to Frank C. Pierson, the AACBS was a useful forum for exchange of ideas among educators but failed to provide leadership in raising admission criteria or requirements for graduation. ${ }^{102}$ It was not until the late 1950 s that similar organizations were launched in Canada; HEC became an active participant. ${ }^{103}$ Laureys chose instead to promote the Société internationale pour l'enseignement commercial (SIEC); it was an effort to validate the European approach to commercial education. The SIEC was founded in Zurich Switzerland, in 1901. ${ }^{104}$ The intent was to provide a forum for educators interested in business education alone as opposed to technical education. An earlier association had dealt with both commercial and technical education. Its first International Conference was held in Lausanne in 1907. Papers on various subjects such as law, economics, administration, commerce, finance, transportation, and customs were given. Eight more conferences were held in Europe before activities ceased after 1914 due to the war. During this period, Germany, Switzerland, Austria, Hungary, and Belgium provided the majority of participants. ${ }^{105}$

Activities of the SIEC were revived in 1926 and Conferences held every year until the onset of World War II. Henry Laureys attended the 1929 conference in Amsterdam and his report was attached to the annual submission to the Secretary of the Province. ${ }^{106}$ He was officially the delegate of the Quebec Government and the only Canadian representative. Laureys gave notification that he would form a Société nationale canadienne pour l'enseignement commercial (SNCEC) which would be affiliated to the SIEC. In 1930 he reported to the provincial secretary that in conjunction with certain professors from McGill that an application had been made for a federal charter. ${ }^{107}$

Despite the lack of related material in the HEC archives, we know that the organization was operating from early 1931. ${ }^{108}$ All the officers were from HEC: Henry Laureys, president; Edouard Montpetit, vice-president; François Vézina, secretary; and Lucien Favreau, treasurer. Directors included Wilfred Bovey, ${ }^{109}$ R. Sugars, ${ }^{110}$ Gilbert Jackson, ${ }^{111}$ and W. C. Clark. ${ }^{112}$ Vézina wrote to every university in Canada inviting them to join. The SIEC history shows that there was one member from Canada in the period 1926-1928, but in 1932 this jumped to $65,{ }^{113}$ undoubtedly following Laureys' initiative. In subsequent years, interest dropped dramatically. Laureys requested permission to go to the 1932 SIEC conference in London, since the Harvard case method which HEC intended to introduce would be discussed; a number of requests were turned down. ${ }^{114}$ Nevertheless, he went on his own. HEC later published his reports on the SIEC Conferences in London ${ }^{115}$ and in Prague (1936). ${ }^{116}$ For the 1936 conference, Secretary David allowed Laureys to use school funds to cover his travel expenses. ${ }^{117}$ None of the histories of other Canadian business schools mention this episode. ${ }^{118}$

Laureys did try to implement the case study method made popular at Harvard. At a 1935 meeting of the conseil pédagogique Léon Lorrain provided a list of French Canadian companies open to submitting their problems as potential cases in the following general areas: import/export commerce; sales; accounting; financial structure 
of the organization; and transport. ${ }^{119}$ At a later meeting in October, Lorrain reported that only three of the companies contacted had replied. ${ }^{120}$ In February 1937 Lucien Favreau who was now in charge of the program reported that two companies had promised input but that none had been received. ${ }^{121}$ It seems like another case of Montreal businessmen dropping the ball when they could have encouraged the business school launched to advance their interests.

The period of Laureys' mandate was one where struggles over primary and secondary education were much more the subject of public debate than issues surrounding higher education. As discussed earlier, in the 1920s a struggle ensued between Catholic teaching Brothers and the clergy who ran the classical colleges. The former had promoted practical education directed towards the middle and lower classes. Laureys could not but support this initiative because it would better prepare incoming students to the HEC. ${ }^{122}$ The leading schools adapting to this trend were Mont St-Louis in Montreal and the Académie commerciale de Québec. ${ }^{123}$

\section{The Minville Era}

Once the Union National Government was elected in 1936, Laureys days were numbered. He had been too close to the Liberal Party which had been in power since the late 1900s and his openness to English speakers and the rest of Canada displeased many nationalists. He was replaced in August 1938 by Esdras Minville. Minville was a 1922 graduate of HEC and he taught there from 1924. He was one of the co-founders of the school's journal the Revue Économique Canadienne in 1925. During the 1930s he became a leader in nationalist circles and was closely associated with the Union National Party.

Another possible explanation for Laureys' replacement was that the HEC was just not living up to expectations. For, despite the improvements made under his leadership, Laureys had still to lament the lack of commitment from the business community. As noted in the conseil de perfectionnement minutes near the end of Laureys' mandate: “ $M$. le Directeur demande comment l'École pourrait intéresser les hommes d'affaires canadiens-français au placement de nos diplômés. Car, c'est malheureusement un fait, le commerce canadien-français est indifférent à nos diplômés." ${ }^{124}$ This sentiment was echoed by Jacques Melançon in the Bulletin published in $1941 .{ }^{125}$ In his opinion, HEC was intended to generate a corps of elite businessmen but its success was limited to producing government bureaucrats and accountants who did not attain leadership positions.

Minville wasted no time in placing his mark on the HEC. One of his first initiatives was to stop publication of the licence theses "as it is expensive and some topics might bring discredit on the School."126 The deciding factor was probably that the majority of the topics dealt with some aspect of geography and this did not conform to the image Minville wanted to create. A more important change was to divide degree program into four specialties: accounting, commerce, industry, and finance, with graduates receiving a corresponding licence in their speciality. ${ }^{127}$ Minville justified these changes based on criticism of the school in the past. ${ }^{128}$ In 1939 he identified the need for a specialist in organization scientifique du travail. This is a recognition 
that scientific management existed. ${ }^{129}$ This led to recent graduate Roger Carbonneau receiving a grant to study at Harvard. Minville even considered changing the name of the school to "Faculty of Commerce" since the current name improperly translated from English was "high school!" 130

According to Foisy-Geoffroy, Minville rejected the so-called American model of university education based on combining teaching and research which was promoted by Marie-Victorin and his associates. He justified retention of the French approach based on economic and cultural arguments. ${ }^{131}$ One indication that the days of this form of pedagogy were numbered was the experience of Jacques Parizeau. He received his licence in 1950 and sponsored by Minville who had offered him a teaching post, he commenced studies at the Paris Institut d'Études Politiques in the autumn of 1951. ${ }^{132}$ As with his mentors Minville and François-Albert Angers, Parizeau became an adherent of François Perroux's ideas. But instead of carrying on and studying for his doctorate in France, he did his Ph.D. at the London School of Economics. According to Pierre Fortin, Parizeau's thesis illustrated his rejection of the philosophical and descriptive approach of French economists taught at HEC. He had embraced the analytical and factual approach of the English-speaking economists. ${ }^{133}$

Under Minville's reign there was a shift in emphasis from geography to one of economics. More specifically he was influenced by Belgian and French theoreticians who gravitated towards social Catholicism. ${ }^{134}$ The leading economist at HEC was François-Albert Angers who had studied at the Paris École libre de sciences politiques. According to Locke, the French economists of the 1930s worked in the literary tradition. They were strong proponents of corporatism and anticapitalist. Theirs was an historical approach to economics and as such they were out of touch with work in economics at English, American, and German universities. ${ }^{135}$ Minville became a central figure in Quebec nationalist circles promoting corporatism and European influences at the expense of American models. He was vice-president of L'Action Corporative formed by Jesuit Joseph-Papin Archambeault in 1938. Archambeault was, like Minville, a proponent of the interdependence of French Canadian culture and Catholicism. The war discouraged their activities and attempts to revive it after the war were unsuccessful. ${ }^{136}$

Minville spent a significant amount of time during his stewardship lobbying to obtain for HEC a status independent of the provincial bureaucracy. This was finally achieved in 1957. But his most important contribution was to stimulate research to identify and develop Quebec's resources. The form of corporatism which he advocated led to the concentration of expertise among provincial bureaucrats. It was the large scale intervention of the Quebec Government in its economy which set off the Quiet Revolution and the emergence and the success of "Québec Inc." 137 HEC graduates took a leading role in this realization.

\section{HEC Becomes a Modern Business School}

Although reluctantly, Pierre Harvey seems to admit that the HEC program had to be changed. The school's founders had failed to recognize the importance of specialization 
which would aid new graduates to obtain initial employment after graduation. Once they were "in" and advanced up the hierarchy they would be well placed to be sympathetic about hiring subsequent graduates of HEC. ${ }^{138}$ Minville's mission to forge collective economic development and maintain the appearances of a French Grande École became chose du passé. ${ }^{139}$

From the time when Roger Carbonneau became Assistant Director in 1958, HEC began to take on quite rapidly the trappings of a North American university school of business. One sign of this was the purchase in 1960 of an IBM 1620 computer to support the mathematics professors' interest in operations research. HEC was however well behind their colleagues at the University of Montreal. The medical faculty initiated research programs in the 1920s. Ecole Polytechnique became active with the arrival of George Welter in 1939. ${ }^{140}$ Another milestone in the rebranding of HEC was the elimination of licence as descriptor of degrees obtained on graduation. It was the Parent commission in the 1960 s which recommended that the BAA/MBA usage be adopted. ${ }^{141}$

Charbonneau graduated from HEC in 1939 and returned from Harvard in 1941 with an MBA to teach at HEC. He became a full professor in 1957 and Director in 1962 when Minville retired. It was under Charbonneau's tutelage that the HEC finally abandoned the European model of a general grounding in commercial subjects. This trend was probably influenced by two reports published in 1959. As with the evaluation of medical schools in 1910, the Carnegie foundation sponsored the work of Frank Pierson. ${ }^{142}$ At about the same time the Ford Foundation sponsored a similar study. ${ }^{143}$ The reports came to similar conclusions. Academic standards needed to be improved along with the entrance requirements for candidates. There was a shortfall in the application of scientific principles to issues of business policy, and too much reliance on general knowledge courses. A greater commitment to research that met high academic standards and which focuses on problems of general significance was needed. Thus, as noted by Vincent Geloso, it was only after 1960 that the HEC had a significant impact on the emergence of an entrepreneurial class. ${ }^{144}$

\section{Conclusion}

The launch of the HEC was intended to expand the entrepreneurial class and increase the number of commercial and industrial leaders among French speakers. It fell short of expectations during its first fifty years of existence. Historians have misrepresented its founding as a realization of the CCDM. In fact it was founded by Quebec political leaders whose excessive attachment to European institutions blinded them to the unsuitability of an academic program foreign to the local environment. There is also a major discrepancy between what was claimed for European business education and actual success in Europe itself. French speaking business leaders in Quebec opposed the course content from the beginning and hired few HEC graduates. It was only when North American approaches to business education were adopted that HEC assumed a leadership role and greater relevance in Quebec's economy.

It is also fair to conclude that the Catholic Church had a negative effect by denigrating business as a career and persistently resisting development of a practical 
stream in the secondary schools. It also had a monopoly on educating and maintaining Quebec's elite whose status was threatened by the emergence of the new professionals: engineers, scientists, and administrators. This was so pervasive that nationalist educators like Minville and Angers who were trying to prepare their students for business careers remained aloof from what was happening in the world around them.

\section{Notes}

1 As quoted in Carter A. Daniel, MBA: The First Century (Lewisburg, Pa.: Bucknell University Press, 1998), 28.

2 Charles N. Cochrane, "The Question of Commerce Courses in Universities," National Conference of Canadian Universities (Proceedings, 1932): 61.

3 Alfred D. Chandler Jr., The Visible Hand. The Managerial Revolution in American Business (Belknap Press: Cambridge, Mass:, 1977) 6-9.

4 Chandler cites the railroad industry as the breeding ground for this revolution.

5 Claude Galarneau, Les collèges classiques au Canada français, 1620-1970 (Montréal: Fides, 1978), 166.

6 Claude Lessard, Le Séminaire de Nicolet, 1803-1969 (Trois-Rivièrs: Éditions du bien public, 1980), 199.

$7 \quad$ Claude Corbo, La mémoire du cours classique: Les années aigres-douces des récits autobiographiques (Outremont: Éditions logiques, 2000), 161. Corbo served as Rector of the University of Quebec at Montreal.

$8 \quad$ Ibid., 86, 164. This was to preserve and spread Catholic/French culture.

$9 \quad$ Ibid., 166.

10 Robert Gagnon, "Archambault, Urgel-Eugène," Dictionary of Canadian Biography, Vol. XIII (2000).

11 This institution will be referred to by its common nickname: Poly.

12 Robert Gagnon, Histoire de l'École Polytechnique, 1873-1990 (Montréal : Boréal, 1991), 60.

13 Paul-André Linteau, René Durocher, and Jean-Claude Robert, Quebec: A History. 1867-1929 (Toronto: J. Lorimer, 1983), 467.

14 Robert Gagnon, Histoire de l'école Le Plateau, 1856-1996 (Montréal: CECM, 1997), 29.

15 Assemblée législative du Québec, Débats de l’Assemblée législative, 8 mars 1907, 343.

16 Esdras Minville, Les Étapes d'une carrière. Causeries autobiographiques et textes connexes (Fides-Montréal, 1988), 39.

17 Biographies Canadiennes-françaises, 1st ed. (Montréal: J.-A. Fortin, 1920). Accountants and engineers were not included as these came to be recognized as distinct professions.

18 Biographies Canadiennes-françaises, 18th ed. (Montréal: Raphael Ouimet, 1960).

19 Barry Boothman, "The Development of Business Education in Canada," in Barbara Austin ed., Capitalizing Knowledge. Essays on the History of Business Education in Canada (Toronto: University of Toronto Press, 2000).

20 Austin, Capitalizing Knowledge.

21 Robert Rumilly, Histoire de l'École des Hautes Études Commerciales de Montréal, 1906-1967 (Montréal: Beauchemin, 1967).

Pierre Harvey, Histoire de l'École des Hautes Études Commerciales de Montréal. Tome 1: 1887-1926 (Montréal: Presses HEC, 1994); Tome II: 1926-1970 (Montréal: Presses HEC, 2002). 
22 The importance of this hurdle should not be underestimated; it is very doubtful that the leadership of the Chambre had the political strength to overcome the resistance of the Church to non-denominational education.

23 François-Albert Angers, Les débuts de l'école des hautes études commerciales. Une institution pionnière dans le milieu québécois. Tome I: 1887-1926. (1987), 53. Unpublished manuscript in HEC archives (AHEC) file: P027.

24 Honoré Gervais, La Patrie, Dec. 21, 1901, cited in Rumilly, Histoire de l'École des Hautes Etudes Commerciales de Montréal, 1906-1967, 19. Gervais was at the same time a law professor at Laval University's Montreal campus.

25 Honoré Gervais, Debates of the House of Commons, Aug. 6, 1904.

26 Chambre de Commerce du District de Montréal, Board Minutes (CCDMBM), May 23, 1900, 402. AHEC file P003. This Alphonse Desjardins had no relation to the founder of the Caisses populaires movement in Quebec.

27 Ibid., December 5, 1900, 487.

28 Ibid., December 19, 1900, 492.

29 Ibid., March 27, 1901, 557.

30 Ibid., November 12, 1902, 303.

31 Ibid., September 3, 1902, 265 \& October 8, 1902, 289.

32 Ibid., April 9, 1903, 419.

33 Ibid., January 10, 1906, 341, January 14, 1906, 352.

34 Gervais and Gouin represented the same area of Montreal.

35 Quebec Liberal Party, Elections de 1919. Le gouvernement Gouin et son oeuvre. Quatorze années de Progrès et de Saine Administration (Quebec: Quebec Liberal Party, 1919), 13.

36 Fernande Roy, Progrès, Harmonie, Liberté. Le libéralisme des milieux d'affaires francophones de Montréal au tournant du siècle (Montréal: Boréal, 1988), 89. Le Moniteur $d u$ Commerce and Le Prix Courant were the main primary sources for this study.

37 Bulletin de la Chambre de Commerce du District de Montréal (BCCDM), Dec. 1, 1900, 97-98. AHEC, file: P003. Gonthier crusaded for many years to raise the status of accountants, and was one of the nine names cited as founding members of L'Institut des comptables et auditeurs de la province de Québec.

38 CCDMBM, AHEC file: P003T-B2-0079, 443.

39 Le Prix Courant, 37, Sept. 1906, 7-8.

40 Le Canada, Sept. 19, 1906, 4.

41 Assemblée législative du Québec, Débats de l'Assemblée législative, 8 mars 1907, 343.

42 CCDMBM, Oct. 3, 1906, 501. AHEC file: P003.

43 Ibid., Jan. 16, 1907, 581.

44 Quebec, Statutes of the Quebec House of Assembly, 7 Ed. VII, Chapter 23 (1907).

45 Ibid., Statutes of Quebec, 7 Ed. VII, Chapter 30.

46 Roy, Progrès, 88, n. 45.

47 Isaie Préfontaine, a construction contractor, was president of the CCDM for 1908-09 and president of the Quebec Federation of Chambers of Commerce, 1909-1912. According to Rumilly (Histoire, 22), Préfontaine was a friend of Lomer Gouin.

48 Joseph Contant was a Montreal pharmacist. He was a founding member of the Chambre and implicated in the launch of the School of Pharmacy at Laval University (Montreal campus).

49 Charles Francis Smith was a financier and company director and apparently a confident of Mgr. Bruchési.

50 Honoré Mercier was Lomer Gouin's son-in-law.

51 In his history of the HEC Rumilly, opines that among supporters in the Chambre for establishing the HEC, only Gervais was for the consular school option. Rumilly (Histoire, 22).

52 Angers, Les débuts de l'école des hautes études commerciales, 33. 
53 Edmund J. James, Education of Business Men in Europe: A Report to the American Bankers' Association Through its Committee on Schools of Finance and Economy (New York: American Bankers' Association, 1893), 168. James became the first director of the Wharton School of Finance and Economy and later president of the University of Illinois.

54 Ibid, Education, 181.

55 Robert R. Locke, Management and Higher Education Since 1940 (Cambridge: Cambridge University Press, 1989), 101.

56 Ibid, Management, 104.

57 Ibid, Management, 102.

58 Robert R. Locke, The End of the Practical Man: Entrepreneurship and Higher Education in Germany, France, and Great Britain, 1880-1940 (Greenwich Conn. \& London, England: JAI Press, 1984), 136.

59 Frederick Ernest Farrington, Commercial Education in Germany (New York: The Macmillan Company, 1914), 197.

60 Future Canadian Prime Minister W. L. Mackenzie King was first offered the job before Gay, but turned it down.

61 Edwin F. Gay, as quoted in Melvin T Copeland, And Mark an Era: The Story of the Harvard Business School (Boston: Little, Brown \& Co., 1958), 27.

62 Stephen A Sass, "The Managerial Ideology in Collegiate Business Education," in Business and Economic History, Papers Presented at the 31 $1^{\text {st }}$ Annual Meeting, (1985), 201.

63 Locke, The End of the Practical Man, 37.

64 Ibid., 91.

65 Ibid., 94.

66 Alvin Finkel et al., History of the Canadian Peoples. 1867 to the Present Vol. II (Toronto: Copp Clark Pitman, 1993), 179-181.

67 Barry Boothman, "The Development of Business Education in Canada," 37, in Austin, Capitalizing.

68 Boothman, "The Development," 47.

69 Barbara Austin, Capitalizing, Introduction, 6.

70 J. J. Servan-Schreiber, The American Challenge (New York: Atheneum, 1968) ix. First published as Le Défi Américan (1967).

71 Edward F. Denison, The Sources of Economic Growth in the United States and the Alternatives Before Us (1962) as quoted in Servan-Schreiber, Le Défi, 75.

72 Paul-André Linteau, "La création des institutions d'enseignement technique et commercial et les rapports Église-État au Québec au début de 20e siècle" in Rubboli, Massimo and Petri, Franca Farnocchia dir., Canada Ieri e Oggi 2. Atti del $7{ }^{\circ}$ Convegno Internazionale di Studi Canadesi, Acireale (Catania)/18-22 maggio 1988, Vol. II, Sezione Storica e Geografica, 44.

73 National Archives of Canada (NAC), Fonds Lomer Gouin, microfilm reel C-2336, "Histoire de l'École."

74 "Letter, Honoré Mercier to Lomer Gouin," Fonds Lomer Gouin, microfilm reel C-2336.

75 Vernon Mallinson, Belgium (London: Ernest Benn Ltd., 1969), 192.

76 CCDMBM, September 9, 1908, AHEC File: P003, 224.

77 Montpetit was a young lawyer working in Honoré Gervais' law office, in 1907. He expressed an interest in teaching at the future HEC and his request for a subsidy to study economics for two years in Paris was granted. Angers, Les débuts de l'école des hautes études commerciales, 78-9.

78 Paul-André Linteau, Histoire de Montréal depuis la Confédération (Montreal: Boréal, 1992), 251.

79 HEC Board Minutes (HECBM) June 13, 1910, AHEC File: P003. 
80 Lechien was available by mid-October, 1910, but Laureys did not arrive until January, 1911.

81 This vote of approval for de Bray's program is surprising in the light of future conflicts; however the board was dominated by men close to Gouin and Gervais.

82 A.-J. de Bray, Revue Économique Canadienne (REC), 2 (1911-1912) 13-14.

83 Jane Marceau, A Family Business? The Making of an International Business Élite (Cambridge: Cambridge University Press, 1989), 23.

84 Harvey, Tome I, 180.

85 CCDMBM, January 1, 1901, AHEC File: P003.

86 Ibid., (November 1909).

87 de Bray, REC (1911-1912), 19.

88 Errol Bouchette, L’indépendance économique des Canadiens-français. (Montreal: Wilson \& Lafleur, 1913), 202, 211.

89 The first preparatory year was initiated in 1915; the second in 1925; and the third in 1934.

90 CCDMBM Oct. 26, 1910, AHEC, File: P003.

91 Le Devoir, October 12, 1910, cited in Harvey (1994) 167.

92 According to Angers (Les débuts, 170), as early as October 1912, 50 members had signed a petition for creation of night courses. His opinion was that the small businessmen of the Chambre wanted clerks with a little more education than that given by the commercial colleges. (Les débuts, 128).

93 CCDMBM (1916).

94 This was a four-masted sailing ship used to train sailors for the Belgian navy.

95 J. Brian Bird. Geography at Mc Gill University. A 50 Year Perspective: 1945-1995. http://cag-acg.ca/files/dept/departments/mcgill.htm. Noted 31/05/2012.

96 Pierre Harvey, Une longue conquête. Histoire de la profession comptable au Québec. (Montreal: Éditions Québec Amérique, 1999).

97 Annual reports by Laureys to the secretary of the Province of Quebec; AHEC: A007/ B2, May 31, 1923, 8. A007/B2, Aug. 9, 1936, 21. The night courses were initiated in 1918 and the correspondence courses in 1924. The latter were intended for those who were not resident of Montreal.

98 Yves Gingras, Pour l'avancement des sciences. Histoire de l'ACFAS. 1923-1993 (Montréal: Boréal, 1994), 16, 62.

99 Annual reports by Laureys to the secretary of the Province of Quebec AHEC file A007/ B2.14 1929 to A007 B2.22 1937.

100 Rousseau was one of Marie-Victorin's students; in 1929 he received his licence ès sciences and in 1934 his doctorate from the University of Montreal

101 Harvey, Tome 2, 91-93.

102 Frank C. Pierson, The Education of American Businessmen: A Study of University-College Programs in Business Administration (New York: McGraw-Hill, 1959), 51.

103 Austin, "The Administrative Sciences Association of Canada, 1957-1999," in Capitalizing, 103.

104 Andrew Moore et al. A Century of International Cooperation in Business Education. 1901-2001 (SIEC, 2001), 1.

105 Moore, A Century, 18.

106 Annual reports by Laureys to the secretary of the Province of Quebec AHEC, A007/B2, 14. August 8, 1929.

107 Annual reports by Laureys to the secretary of the Province of Quebec AHEC, A007/B2, 15. June 25, 1930.

108 Letter from François Vézina, Feb. 5, 1931 enclosing application forms for membership and addressed to Canadian Commerce Faculty directors. File: "Canadian Society for Commercial Education,” McGill Archives file: RG. 28, Cont. 2, 1326A, Acc. No. 1193. 
109 Bovey was a director of the Montreal Board of Trade and the head of external relations for McGill University.

110 Sugars was the dean of the McGill Commerce department (1916-1938) and former accounting instructor at the HEC. He attended the SIEC conference in Madrid in 1914.

111 Jackson was the dean of the School of Commerce, University of Toronto.

112 Clark was the dean of the School of Commerce, Queens' University.

113 Moore, A Century, 37.

114 Letter Laureys to secretary of the Province of Quebec, AHEC file: A007/B2, 17. 1932.

115 Henry Laureys, Report by Dr. Henry Laureys Concerning the International Conference on Commercial Education held in London from the 25 th to the 29th of July 1932 (Montreal: HEC, 1932).

116 Henry Laureys, The Prague Conference. Report (Montreal: HEC, 1936).

117 Letter Laureys to Secretary of the Province of Quebec, AHEC April 4, 1935, A007 file: B2, 201935

118 Austin, Capitalizing, Chapters 2-9.

119 Minutes of the conseil pédagogique (MCPed), March 14, 1935, 166. AHEC file: A003,.

120 MCPed, Oct. 17, 1935, 174, AHEC file: A003.

121 MCPed, Feb. 25, 1937, 193. AHEC file: A003

122 Louise Bienvenue, "Former à l'académie commerciale ou au collège classique? Un débat sur l'enseignement secondaire des garçons au début des années 1920," Historical Studies in Education, 21 (Spring 2009), 4-13.

123 From 1925, their graduates were accepted directly into the first year of the licence, see: Harvey, Tome I, 268.

124 Minutes of the conseil de perfectionnement (MCPer), March 14, 1935, 167, AHEC file: A005.

125 BCCDM (July, 1941), as cited in Harvey, Tome II, 177.

126 Ibid., Tome II (Aug. 8, 1935), 211.

127 Ibid., Tome II (Nov. 2, 1938), 224.

128 Ibid., Tome II (March 6, 1940), 274.

129 Ibid., Tome II (June 20, 1939), 246.

130 MCPer, Jan. 20, 1943 30. AHEC file: A005.

131 Dominique Foisy-Geofffroy. Esdras Minville. Nationalisme économique et catholicisme social au Québec durant l'entre-deux-guerres. (Montreal : Septentrion 2004), 98.

132 Pierre Duchesne, Jacques Parizeau. Tome I. Le Croisé. 1930-1970. (Montréal: Éditions Québec Amérique 2002) 110-113.

133 Duchesne, Jacques, 162-3.

134 Jonathan Fournier, "Les économistes canadiens-français pendant l'entre-deux-guerres: entre la science et l'engagement," Revue d'histoire de l'Amérique française, 58:3 (2005), 391. See also Ruth Dupré et al. D’une revue d'affaires à une revue d'économique: 75 dans la vie de l'actualité économique (Montréal: École des hautes études commerciales, 2000).

135 Locke, The End of the Practical Man, 112.

136 Alain Gagnon, "L'influence de l'Église sur l'évolution socio-économique du Québec, de 1850 à 1950," Action nationale 69 (1979), 252-277.

137 Yves Bélanger, Québec Inc. L'entreprise québécoise à la croisée des chemins (Montréal: Éditions Hurtubise HMH, 1998), 14, 20.

138 Harvey, Tome II, 175.

139 Ibid. Tome II, 335.

140 Jean-Marie Desrochers and Gagnon, Robert, "Georges Welter et l'émergence de la recherche a l'École Polytechnique de Montréal, 1939-1970" in Recherches sociographiques, 24:1 (1983), 33-54. 
141 Angers, Les débuts, 156. Granting of the licence was a practice imported from Europe; this qualified the recipient to study for a doctorate, but was unfamiliar to Canadians.

142 Frank C. Pierson, The Education, 51.

143 Robert A. Gordon and James E. Howell, Higher Education for Business (New York: Columbia University Press, 1959).

144 Vincent Geloso, Du grand rattrapage au déclin tranquille (Montréal: Les Éditions Accent Grave, 2013), 137. 